\title{
Lindane, a gap junction blocker, suppresses FSH and transforming growth factor $\beta 1$-induced connexin 43 gap junction formation and steroidogenesis in rat granulosa cells
}

\author{
Ferng-Chun $\mathrm{Ke}^{1}$, Su-Huan Fang ${ }^{2}$, Ming-Ting Lee ${ }^{3}$, \\ Shiow-Yhu Sheu ${ }^{2}$, Si-Yi Lai ${ }^{2}$, Yun Ju Chen ${ }^{2}$, Fore-Lien Huang ${ }^{1}$, \\ Paulus S Wang ${ }^{2}$, Douglas M Stocco ${ }^{4}$ and Jiuan-Jiuan Hwang ${ }^{2}$ \\ ${ }^{1}$ Institute of Molecular and Cellular Biology, School of Life Sciences, National Taiwan University, Taipei 106, Taiwan \\ ${ }^{2}$ Institute of Physiology, School of Medicine, National Yang-Ming University, Taipei 112, Taiwan \\ ${ }^{3}$ Institute of Biological Chemistry, Academia Sinica, Taipei 115, Taiwan \\ ${ }^{4}$ Department of Cell Biology and Biochemistry, Texas Tech University Health Sciences Center, Lubbock, Texas 79430, USA \\ (Requests for offprints should be addressed to J-J Hwang, Institute of Physiology, School of Medicine, National Yang-Ming University, 155 Linong Street, \\ Section 2, Taipei 112, Taiwan; Email: jiuanh@ym.edu.tw)
}

\begin{abstract}
The present study was designed to explore the role of gap junctions in follicle-stimulating hormone (FSH) and transforming growth factor $\beta 1$ (TGF $\beta 1$ )-stimulated steroidogenesis in ovarian granulosa cells of gonadotropin-primed immature rats. There were three specific aims. First, we investigated the effect of FSH and TGF $\beta 1$ as well as lindane (a general gap junction blocker) on the level of connexin43 (Cx43), the major gap junction constituent in granulosa cells, and on gap junction function. The second aim was to determine the effect of lindane on FSH and TGF $\beta 1$-stimulated progesterone production and the levels of two critical players, cytochrome $\mathrm{P} 450$ side-chain cleavage $(\mathrm{P} 450 \mathrm{scc})$ enzyme and steroidogenic acute regulatory (StAR) protein. The third aim was to further investigate the specific involvement of $\mathrm{Cx} 43$ gap junctions in $\mathrm{FSH}$ and TGF $\beta 1$-stimulated steroidogenesis using a Cx43 mimetic peptide blocker. Immunoblotting analysis showed that FSH plus TGF $\beta 1$ dramatically increased the levels of phosphorylated Cx43 without significantly influencing the level of nonphosphorylated $\mathrm{Cx} 43$, and this stimulatory effect was completely suppressed by lindane. Also,
\end{abstract}

immunofluorescence analysis showed that Cx43 immunoreactivity increased in the FSH plus TGF $\beta 1$-treated group and predominantly appeared in a punctate pattern at cell-cell contact sites, and lindane reduced such cell periphery immunostaining. Furthermore, TGF $\beta 1$ enhanced the FSH-induced gap junction intercellular communication and lindane completely suppressed this effect. In addition, lindane suppressed the FSH and TGF $\beta 1$-stimulated increases in progesterone production and the levels of P450scc enzyme and StAR protein. This study demonstrates a clear temporal association between the Cx43 protein level/gap junction communication and progesterone production in rat ovarian granulosa cells in response to FSH and TGF $\beta 1$ as well as lindane. Furthermore, a specific $\mathrm{Cx} 43$ gap junction blocker suppressed FSH plus TGF $\beta 1$-stimulated progesterone production. In conclusion, this study suggests that $\mathrm{Cx} 43$ gap junctions may play a critical role in FSH plus TGF $\beta 1$-stimulated progesterone production in rat ovarian granulosa cells. Journal of Endocrinology (2005) 184, 555-566

\section{Introduction}

Gap junctions are intercellular plasma membrane channels that allow direct intercytoplasmic movement of small molecules $(<1 \mathrm{kDa})$ such as nutrients, ions and second messengers between neighboring cells (Kumar \& Gilula 1996). They are formed by the docking of connexons from two adjacent cells, and each connexon is thought to be a hexamer of connexin proteins (Kumar \& Gilula 1996). Gap junctions are believed to play essential roles in organogenesis and the control of cell proliferation and differentiation (Kumar \& Gilula 1996, Yamasaki \& Naus 1996). Such communication among ovarian cells via gap junctions may also be involved in the control of follicular development, oocyte meiotic maturation, and luteal growth and regression (Grazul-Bilska et al. 1997, Ackert et al. 2001, Kidder \& Mhawi 2002). Gap junctions between ovarian granulosa cells contain predominantly connexin43 (Cx43) which is present at all stages of follicle development with large antral follicles having the strongest 
immunostaining intensity (Mayerhofer \& Garfield 1995, Granot \& Dekel 1997, Kidder \& Mhawi 2002). Recent studies reported that in $\mathrm{Cx} 43$-deficient female mice, ovarian follicles were arrested in the early preantral stages, and that cellular communication between granulosa cells was disrupted (Juneja et al. 1999, Ackert et al. 2001, Kidder \& Mhawi 2002, Gittens et al. 2003), suggesting that $\mathrm{Cx} 43$ gap junction communication is critical for ovarian folliculogenesis.

At present, our understanding of the hormonal control of Cx43 gap junction in ovarian cells is limited. Folliclestimulating hormone $(\mathrm{FSH})$ is the major regulator of growth and development of antral follicles in the ovary (Hirshfield 1991, Richards 2001). It was reported that FSH stimulated gap junction formation and turnover in rat ovarian granulosa cells (Burghardt \& Matheson 1982). The expression of $\mathrm{Cx} 43$ was increased with follicular growth and decreased after the ovulatory luteinizing hormone surge and during follicular atresia (Schreiber et al. 1993, Wiesen \& Midgley 1993, 1994, Mayerhofer \& Garfield 1995, Okuma et al. 1996, Granot \& Dekel 1997). Recently, FSH was demonstrated to increase intercellular communication as well as the levels of $\mathrm{Cx} 43 \mathrm{mRNA}$ in a rat ovarian granulosa cell line (Sommersberg et al. 2000). In the male, FSH also increased gap junction communication in primary testicular Sertoli cells, the equivalent to granulosa cells in the female (Pluciennik et al. 1994). Apart from external hormonal regulation, ovarian cells function in response to local factors including cytokines such as transforming growth factor $\beta 1$ (TGF $\beta 1$ ) (Benahmed et al. 1993). TGF $\beta 1$ plays important autocrine/paracrine roles in modulating ovarian cell functions including the facilitation of gonadotropin-induced proliferation and differentiation (induction of luteinizing hormone receptors, progesterone production and aromatase activity) and the ovulatory process (Dorrington et al. 1993, Inoue et al. 2002). TGF $\beta 1$ was reported to increase the mRNA and protein levels of $\mathrm{Cx} 43$ in endothelial cells (Larson et al. 1997, 2001). In contrast, TGF $\beta 1$ inhibited gap junction intercellular communication and decreased the phosphorylation of Cx43 in osteoblasts (Wyatt et al. 2001) and glioma cells (Robe et al. 2000). It remains elusive as to whether TGF $\beta 1$ modulates gap junction function in ovarian granulosa cells where gap junctions are well developed.

Therefore, the objective of the present study was to investigate the role of gap junctions in FSH and TGF $\beta 1$ stimulated progesterone production (a marker of differentiation) in rat ovarian granulosa cells. There were three specific aims to achieve this goal; The first was to determine the effect of FSH and TGF $\beta 1$ as well as a general gap junction blocker, lindane ( $\gamma$-hexachlorocyclohexane), on the level of gap junction protein $\mathrm{Cx} 43$ in rat granulosa cells. Lindane was reported to rapidly inhibit gap junction communication and with longer treatment it caused a loss of gap junctions and phosphorylated Cx43 proteins in liver epithelial cells (Guan et al. 1995) and Sertoli cells (Defamine et al. 2001). In addition, lindane has been widely used as a pesticide in agriculture and has been reported to accumulate in the ovary and testis (Szymczynski \& Waliszewski 1983, Lindenau et al. 1994, Dalsenter et al. 1996). Thus, the second aim was to investigate the effects of lindane on FSH and TGF $\beta 1$ stimulated progesterone production as well as on two key players in steroidogenesis, steroidogenic acute regulatory (StAR) protein and cytochrome P450 cholesterol side-chain cleavage (P450scc) enzyme. StAR protein is responsible for mediating the rate-limiting step in steroidogenesis, the transport of cholesterol from the outer to the inner mitochondrial membrane (Christenson \& Strauss 2001, Stocco 2001) where P450scc enzyme resides and catalyzes the initial step of steroid hormone biosynthesis, the production of pregnenolone. The third aim was to determine the specific involvement of $\mathrm{Cx} 43$ gap junction on FSH andTGF $\beta 1$-stimulated progesterone production by employing a $\mathrm{Cx} 43$ mimetic peptide blocker. Cx43 peptide blockers have been reported to interfere with gap junction communication in airway cells (Boitano \& Evans 2000) and aortic smooth muscle cells transfected with Cx43 cDNA (Kwak \& Jongsma 1999).

\section{Materials and Methods}

\section{Materials}

Ovine FSH (oFSH-19-SIAFP) and equine chorionic gonadotropin were purchased from the National Hormone and Peptide Program, National Institute of Diabetes and Digestive and Kidney Diseases, and Dr A F Parlow (Harbor-UCLA Medical Center, Torrance, CA, USA). Recombinant human TGF $\beta 1$ was obtained from R\&D Systems, Inc. (Minneapolis, MN, USA). Penicillin and streptomycin were from GIBCO Invitrogen Corporation (Carlsbad, CA, USA). Mouse monoclonal antibody against Cx43 was obtained from BD Transduction Laboratories (Lexington, KY, USA). Antiserum against StAR protein was produced and characterized as previously described (Clark et al. 1994). Antiserum against P450scc enzyme (Hu et al. 1991) was kindly provided by Dr Bon-Chu Chung (Academia Sinica, Taipei, Taiwan). Mouse monoclonal antibody against $\beta$-actin, fluorescein isothiocyanateconjugated anti-mouse immunoglobulin antibody, bovine alkaline phosphatase, 4',6-diamidino-2-phenylindole dihydrochloride (DAPI) and Lucifer Yellow were from Sigma Chemical Co. (St Louis, MO, USA). All other chemicals used were purchased from Sigma Chemical Co. unless otherwise stated.

\section{Animals}

Immature Sprague-Dawley rats (23-25 days) were obtained from the Animal Center at National Yang-Ming 
University (Taipei, Taiwan). Rats were maintained under controlled temperature $\left(20-23^{\circ} \mathrm{C}\right)$ and light conditions (14 h light:10 h darkness). Food (Lab Diet from PMI Feeds Inc., St Louis, MO, USA) and water were available ad libitum. This study was conducted in accordance with both the United States National Research Council's Guide for the Care and Use of Laboratory Animals and institutional guidelines.

\section{Cell culture and treatment}

Isolation of ovarian granulosa cells from equine chorionic gonadotropin-treated immature rats was performed as previously described (Hwang et al. 1996). Briefly, immature rats were injected once subcutaneously with $15 \mathrm{IU}$ pregnant mare serum gonadotropin for $48 \mathrm{~h}$ to induce the development of multiple follicles to antral follicle stage. Ovarian granulosa cells of mid- to large-sized antral follicles were then isolated and plated into 24-well plates coated with matrigel (derived from Engelbreth-HolmSwarm sarcoma tumors; Sigma Chemical Co.) at approximately $5 \times 10^{5}$ viable cells per well in $500 \mu$ l of growth medium (Dulbeco's Modified Eagle's Medium (DMEM)/ F-12, $1: 1$ medium containing $2 \mu \mathrm{g} / \mathrm{ml}$ bovine insulin, $0 \cdot 1 \%$ fatty acid-free BSA, $100 \mathrm{U} / \mathrm{ml}$ penicillin and $100 \mu \mathrm{g} / \mathrm{ml}$ streptomycin) and allowed to attach for $24 \mathrm{~h}$ at $37^{\circ} \mathrm{C}, 5 \% \mathrm{CO}_{2}-95 \%$ air. Cultured cells were then washed and incubated in $500 \mu \mathrm{l}$ of incubation medium (DMEM/F12, 1:1 medium containing 0.1\% lactalbumin hydrolysate, $100 \mathrm{U} / \mathrm{ml}$ penicillin and $100 \mu \mathrm{g} / \mathrm{ml}$ streptomycin) for $24 \mathrm{~h}$ before the beginning of treatment. Cells were treated once with FSH and/or TGF $\beta 1$ for 24 or $48 \mathrm{~h}$. To study the effect of lindane on steroidogenesis, cells were pretreated with dimethylsulfoxide (DMSO) vehicle or various doses of lindane for $24 \mathrm{~h}$, and then treated with vehicle, $10 \mathrm{ng} / \mathrm{ml} \mathrm{FSH}$ and/or $5 \mathrm{ng} / \mathrm{ml}$ TGF $\beta 1$ in the absence (DMSO vehicle) or presence of various doses of lindane for an additional 24 or $48 \mathrm{~h}$. To study the effect of $\mathrm{Cx} 43$ mimetic peptides on steroidogenesis, cells were cultured in serum-free media as described above except that antibiotics were omitted to prevent possible interaction with the oligopeptides (Kwak \& Jongsma 1999). Cells were treated with Cx43 peptide blocker (containing the rat $\mathrm{Cx} 43$ extracellular domain sequence, amino acid residues 180-195) or control peptide (containing intracellular domain sequence, amino acid residues 201-211) during plating and allowed to attach for $24 \mathrm{~h}$. Cells were then pretreated with $\mathrm{Cx} 43$ mimetic peptides for another $24 \mathrm{~h}$ and then treated with vehicle or $10 \mathrm{ng} / \mathrm{ml} \mathrm{FSH}$ plus $5 \mathrm{ng} / \mathrm{ml}$ TGF $\beta 1$ in the absence or presence of the $\mathrm{Cx} 43$ peptides for an additional $48 \mathrm{~h}$. In every experiment each treatment group was performed in triplicate. At the end of incubation, conditioned media were collected, cleared by centrifugation, and stored at $-70^{\circ} \mathrm{C}$ until assayed for progesterone content by enzyme immunoassay. Cell number was determined using the crystal violet assay as previously described (Gillies et al. 1986).

Enzyme immunoassay of steroids

Progesterone levels in conditioned media were measured using enzyme immunoassay as previously described (Ke et al. 2004). Progesterone antibody was produced and characterized as previously described (Lu et al. 1996). The sensitivity of the assay was 5 pg per well, and the intra- and inter-assay coefficients of variation were $4 \cdot 0 \%(n=3)$ and $7 \cdot 8 \%(n=3)$ respectively.

\section{Immunoblot analysis of Cx43, StAR protein and P450scc enzyme}

Granulosa cells (approximate 5 to $6 \times 10^{6}$ ) were cultured in matrigel-coated $60 \mathrm{~mm}$ culture dishes, pretreated with DMSO vehicle or $40 \mu \mathrm{M}$ lindane for $24 \mathrm{~h}$, and then treated with control vehicle, $10 \mathrm{ng} / \mathrm{ml} \mathrm{FSH}$ and/or $5 \mathrm{ng} / \mathrm{ml} \mathrm{TGF} \beta 1$ in the absence (DMSO vehicle) or presence of lindane for an additional 24 or $48 \mathrm{~h}$. The cells were washed with ice-cold PBS and then extracted with lysis buffer (radioimmunoprecipitation assay buffer containing a protease inhibitor cocktail and $1 \mathrm{mM}$ of the phosphatase inhibitors $\mathrm{Na}$ orthovanadate and $\mathrm{NaF}$ ). Cell lysates were analyzed for the presence of $\mathrm{Cx} 43$, StAR protein and P450scc enzyme with $\beta$-actin used as an internal control. Cell lysates $(30 \mu \mathrm{g}$ protein each) were analyzed by $10 \%$ SDS-polyacrylamide gel electrophoresis and electroblotting as previously described (Ke et al. 2004). Specific signals were detected using an enhanced chemiluminescence (ECL) detection system (Amersham Pharmacia Biotech UK Limited, Little Chalfont, Buckinghamshire, England) according to the manufacturer's protocol. Relative quantification of ECL signals on $\mathrm{x}$-ray film was analyzed using a two-dimensional laser scanning densitometer (Molecular Dynamics, Sunnyvale, CA, USA). To identify the phosphorylated forms of Cx43, aliquots of the cell lysate $(40 \mu \mathrm{g}$ protein each) were digested with or without 60 units of bovine alkaline phosphatase at $37^{\circ} \mathrm{C}$ for $2 \mathrm{~h}$ in the absence or presence of alkaline phosphatase inhibitors $(3 \mathrm{mM} \mathrm{Na}$ orthovanadate and $\mathrm{NaF}$ ) prior to immunoblotting.

\section{Immunofluorescence analysis of $\mathrm{C} \times 43$}

Granulosa cells (approximate $2 \cdot 5 \times 10^{6}$ ) were cultured in matrigel-coated $35 \mathrm{~mm}$ culture dishes, pretreated with DMSO vehicle or $40 \mu \mathrm{M}$ lindane for $24 \mathrm{~h}$, and then treated with control vehicle, $10 \mathrm{ng} / \mathrm{ml} \mathrm{FSH}$ or FSH plus $5 \mathrm{ng} / \mathrm{ml}$ TGF $\beta 1$ in the absence (DMSO vehicle) or presence of lindane for an additional $48 \mathrm{~h}$. Cells were rinsed with PBS twice, fixed in 4\% paraformaldehyde at room temperature for $30 \mathrm{~min}$, washed with PBS and 
permeabilized with $0 \cdot 05 \%$ Triton X-100 for $2 \mathrm{~min}$. Cells were washed, blocked in 3\% BSA plus 3\% normal goat serum for $1 \mathrm{~h}$ and then sequentially incubated for $1 \mathrm{~h}$ with Cx43 monoclonal antibody (1:250 dilution) and fluorescein isothiocyanate-conjugated anti-mouse immunoglobulin antibody (1:100). Nuclei of cells were also stained using $2 \mu \mathrm{g} / \mathrm{ml}$ DAPI for $1 \mathrm{~h}$. Photographs were taken using a fluorescence microscope (Olympus BX50, Shinjuku-Ku, Tokyo, Japan) at x 100 magnification and SPOT image capture system (Diagnostic Instruments, Inc., Sterling Heights, MI, USA).

Gap junction communication: scrape-loading dye transfer assay

Granulosa cells (approximate $3 \times 10^{6}$ ) were cultured in matrigel-coated $35 \mathrm{~mm}$ culture dishes, pretreated with DMSO vehicle or $40 \mu \mathrm{M}$ lindane for $24 \mathrm{~h}$, and then treated with control vehicle, $10 \mathrm{ng} / \mathrm{ml} \mathrm{FSH}$ or FSH plus $5 \mathrm{ng} / \mathrm{ml} \mathrm{TGF} \beta 1$ in the absence (DMSO vehicle) or presence of lindane for an additional 24 or $48 \mathrm{~h}$. The gap junction function was assessed as previously described (El-Fouly et al. 1987, El-Sabban et al. 2003, Yeh \& Hu 2003) with modifications. At the end of culture, the confluent monolayer of cells were scraped with a sharp blade to create two fine linear wounds, quickly rinsed with PBS and loaded with $1 \mathrm{ml}$ of Lucifer Yellow (LY, $1 \mathrm{mg} / \mathrm{ml}$ in incubation medium). The dye solution was removed 5 seconds later and the culture was quickly rinsed four times with PBS. The amount of LY dye transferred from the scraped edge to the neighboring cells was examined under fluorescent microscope at x 100 magnification and SPOT image capture system (Diagnostic Instruments). Two representative images were taken per dish. The relative extent of cell coupling was determined by the following two methods; first, the relative number of LY positive cells was calculated as the ratio of total number of LY-labeled cells to the cell number on the scraped edge (determined by the corresponding phase contrast image) relative to that of the control group (Yeh \& Hu 2003). Secondly, the relative fluorescent intensity was calculated as the ratio of total fluorescent intensity of LY (determined using ImageQuant analysis system, Molecular Dynamics) to the cell number on the scraped edge relative to that of the control group (El-Sabban et al. 2003).

\section{Statistics}

Data are presented as the mean \pm S.E. and were analyzed by ANOVA and Duncan's multiple range test at a significance level of 0.05 using the general linear model of the SAS program (SAS Institute Inc., Cary, NC, USA). Differences between two treatment groups were analyzed using the Student's $t$-test at a significance level of $0 \cdot 05$.
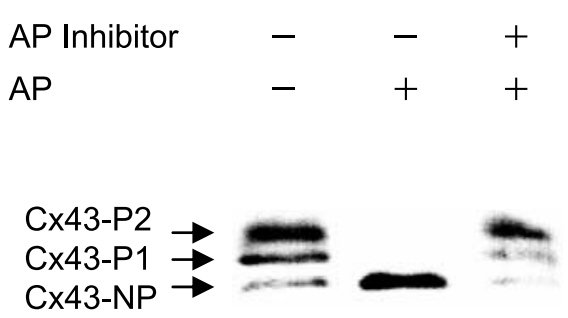

Figure 1. Characterization of $\mathrm{Cx} 43$ in rat ovarian granulosa cells. Cells were treated with $10 \mathrm{ng} / \mathrm{ml} \mathrm{FSH}$ plus $5 \mathrm{ng} / \mathrm{ml} \mathrm{TGF} \beta 1$ for $48 \mathrm{~h}$. Cell lysates were prepared, and aliquots of $40 \mu \mathrm{g}$ protein each were digested with or without alkaline phosphatase (AP; 60 units, $37^{\circ} \mathrm{C}$ for $2 \mathrm{~h}$ ) and in the absence or presence of AP inhibitors ( $\mathrm{Na}$ orthovanadate and $\mathrm{NaF}$ ), and then analyzed by immunoblotting using an antibody that recognizes nonphosphorylated (Cx43-NP) and phosphorylated forms of Cx43 (Cx43-P1, Cx43-P2).

\section{Results}

Effect of FSH, TGF 1 and lindane (a nonselective gap junction blocker) on connexin 43 protein levels and gap junction communication

Gap junctions, predominantly composed of $\mathrm{Cx} 43$, are well developed in ovarian granulosa cells. To investigate the potential role of gap junctions in ovarian steroidogenesis, we first determined the regulatory role of FSH and TGF $\beta 1$ as well as lindane on the protein levels of $\mathrm{Cx} 43$ in rat granulosa cells using immunoblotting and immunofluorescence techniques. Cx43 predominantly existed in two phosphorylated forms, designated $\mathrm{Cx} 43-\mathrm{P} 1$ and Cx43-P2, and both could be converted to the nonphosphorylated form (Cx43-NP) by alkaline phosphatase (Figure 1). FSH moderately increased the level of Cx43-P2 (but not Cx43-P1) on day 1 of culture and the increment subsided on day 2 of culture (Figure 2). TGF $\beta 1$ together with FSH markedly increased the levels of both Cx43-P1 and Cx43-P2 from day1 to day 2 of culture, while TGF $\beta 1$ alone had no significant effect (Figure 2). Lindane, on the other hand, completely suppressed FSH and TGF $\beta 1$-increased Cx43-P levels to control values in day 1 and day 2 cultures (Figure 2). Also, lindane moderately reduced $\mathrm{Cx} 43-\mathrm{P}$ levels in $\mathrm{FSH}$-treated or TGF $\beta 1$-treated groups on day 2 of culture (Figure 2). The level of $\mathrm{Cx} 43-\mathrm{NP}$ remained scarce in all the treatment groups. We then determined the cellular localization of Cx43 using immunofluorescence. Immunostaining of Cx43 appeared predominantly as a punctate pattern at cell-cell contact sites, with the highest intensity in the FSH plus TGF $\beta 1$-treated group as compared with the FSHtreated and the control groups (Figure 3). In addition, lindane reduced the FSH and TGF $\beta 1$-stimulated increase in $\mathrm{Cx} 43$ cell periphery immunostaining (Figure 3). Furthermore, gap junction communication was examined using the scrape loading-dye transfer assay. The extent of cell coupling on day 1 and day 2 culture was increased in FSH- and FSH plus TGF $\beta 1$-treated groups as compared 
(A)

DAY 1

DAY 2

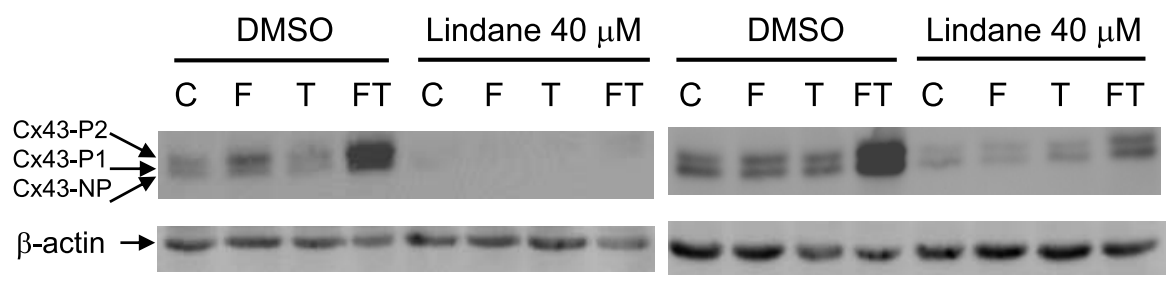

(B)

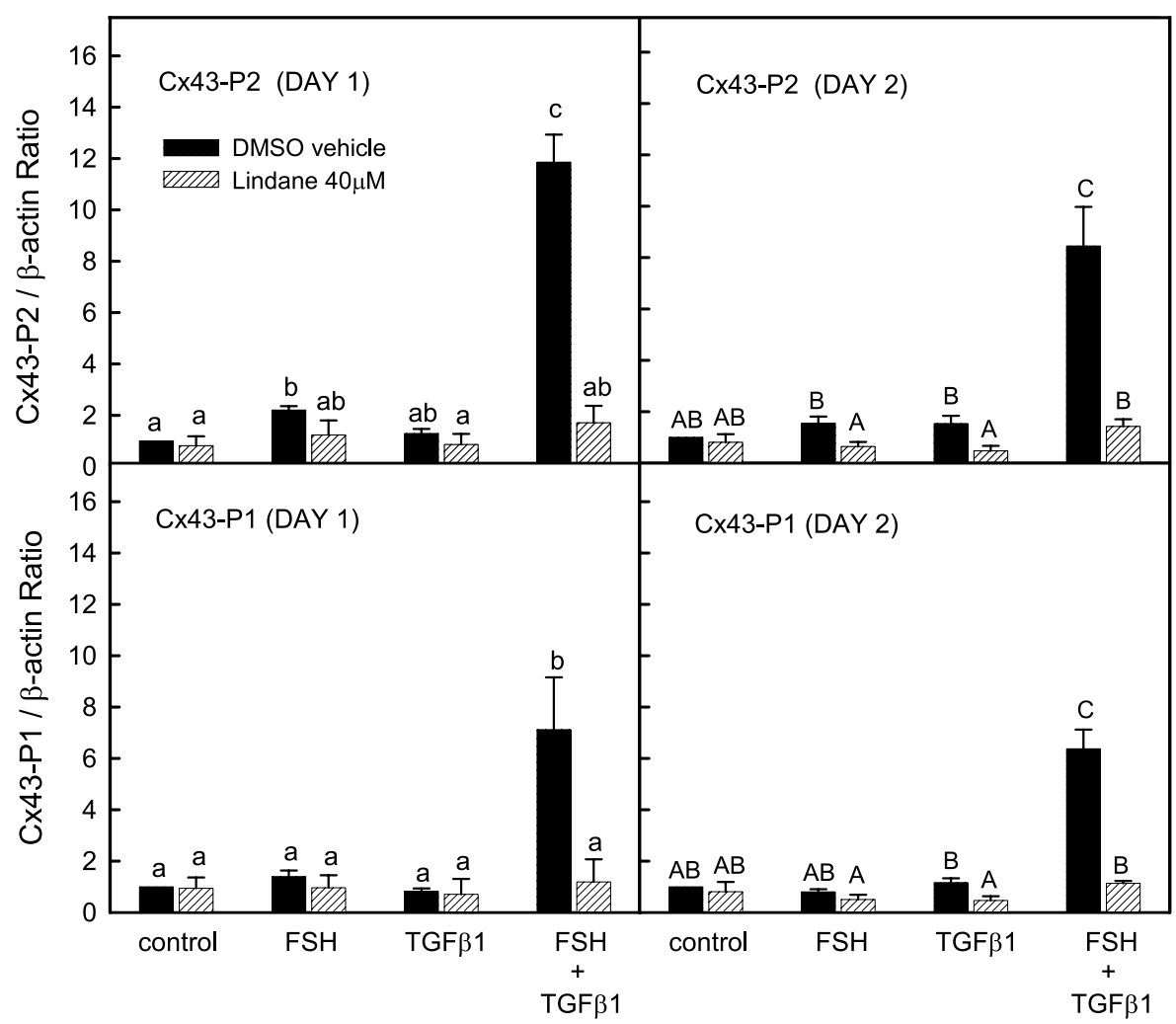

Figure 2. Effects of FSH, TGF $\beta 1$ and lindane on the $\mathrm{Cx} 43$ level in rat ovarian granulosa cells. Cells were plated and allowed to attach for $24 \mathrm{~h}$, pretreated with DMSO vehicle or $40 \mu \mathrm{M}$ lindane for $24 \mathrm{~h}$, and then treated with vehicle, $10 \mathrm{ng} / \mathrm{ml} \mathrm{FSH}$ and/or $5 \mathrm{ng} / \mathrm{ml} \mathrm{TGF} \beta 1$ in the absence (DMSO vehicle) or presence of lindane for an additional $24 \mathrm{~h}$ (DAY 1) or $48 \mathrm{~h}$ (DAY 2). (A) Cell lysates were prepared for immunoblotting analysis of $\mathrm{C} \times 43$, with $\beta$-actin used as an internal control, and quantification was performed using scanning densitometry. (B) Data are expressed as the mean ( \pm S.E.) density ratio of $C \times 43: \beta$-actin relative to that of the respective control value from three independent experiments. Different lower-case (or upper-case) letters indicate significant differences among treatment groups $(P<0 \cdot 05)$. Cx43-P1, Cx43-P2: phosphorylated forms of Cx43. C: control; F: FSH; T: TGF $\beta 1$; FT: FSH+ TGF $\beta 1$. The levels of $\mathrm{Cx} 43-\mathrm{NP}$ were scarce in all treatment groups.

with the control group, with lindane suppressing this effect of FSH plus TGF $\beta 1$ (FSH plus TGF $\beta 1>\mathrm{FSH}>$ control $\approx$ FSH plus TGF $\beta 1$ plus lindane) (Figure 4).

\section{Effects of gap junction blockers on FSH and}

TGF $\beta 1$-stimulated steroidogenesis

Since lindane suppressed the FSH plus TGF $\beta 1$-stimulated increases in the phosphorylated Cx43 levels and gap junction communication in rat granulosa cells, we then determined the effect of lindane on FSH and TGF $\beta 1$ stimulated progesterone production (a marker of differentiation) as well as on the levels of StAR protein and P450scc enzyme (two critical players in progesterone production). Lindane dose-dependently $(10$ to $40 \mu \mathrm{M})$ suppressed FSH plus TGF $\beta 1$-stimulated progesterone production during days 1 to 2 of culture (Figure 5), but had no significant effect on basal and FSH-stimulated 

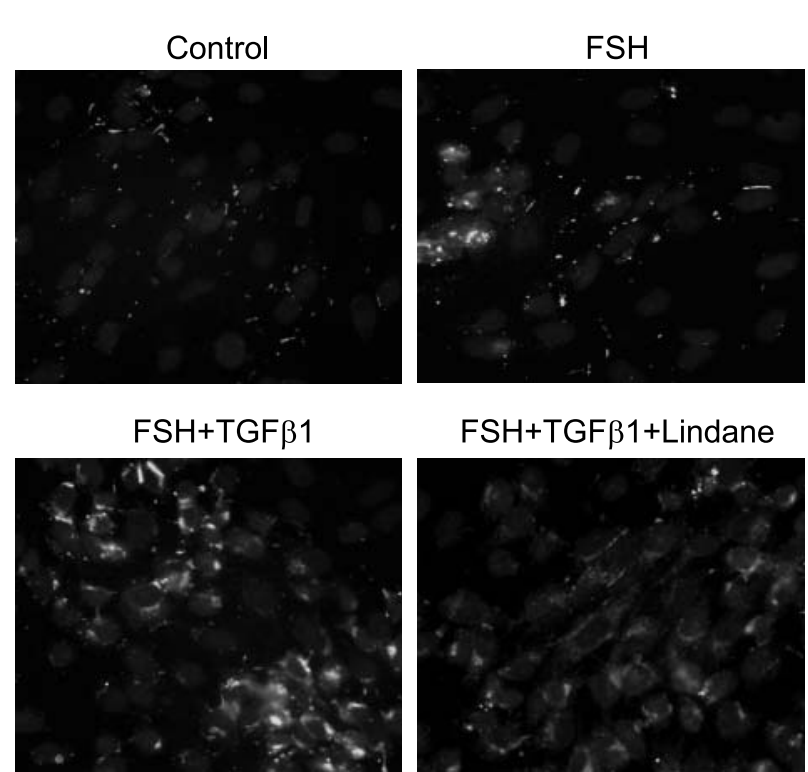

FSH+TGF $\beta 1+$ Lindane

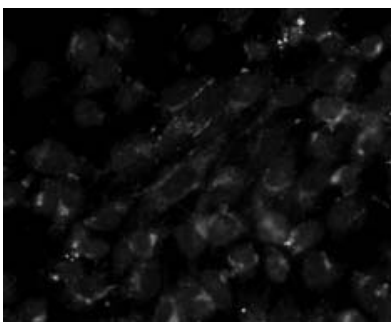

Figure 3. Effects of FSH, TGF $\beta 1$ and lindane on the cellular localization of $\mathrm{Cx} 43$ in rat ovarian granulosa cells. Cells were plated and allowed to attach for $24 \mathrm{~h}$, pretreated with DMSO vehicle or $40 \mu \mathrm{M}$ lindane for $24 \mathrm{~h}$, and then treated with vehicle, $10 \mathrm{ng} / \mathrm{ml} \mathrm{FSH}$, or FSH plus $5 \mathrm{ng} / \mathrm{ml}$ TGF $\beta 1$ in the absence (DMSO vehicle) or presence of lindane for an additional $48 \mathrm{~h}$. Cells were then fixed, permeabilized and analyzed for the localization of Cx43 using immunofluorescence. Nuclei of cells were also stained using DAPI. Representative photographs from one experiment are presented. Similar results were observed in three independent experiments. Note that lindane suppressed the FSH plus TGF $\beta 1$-induced increase in the Cx43 immunostaining intensity predominantly at the cell-cell contact sites.

steroidogenesis (Figure 5). Also, TGF $\beta 1$ alone or in the presence of lindane did not affect progesterone production (data not shown).

We further demonstrated that FSH and TGF $\beta 1$ as well as lindane exerted a differential regulation of StAR protein and P450scc enzyme. Consistent with our most recent

Figure 4. Effects of FSH, TGF $\beta 1$ and lindane on gap junction communication in rat ovarian granulosa cells. Cells were plated and allowed to attach for $24 \mathrm{~h}$, pretreated with DMSO vehicle or $40 \mu \mathrm{M}$ lindane for $24 \mathrm{~h}$, and then treated with vehicle, $10 \mathrm{ng} / \mathrm{ml}$ $\mathrm{FSH}$, or FSH plus $5 \mathrm{ng} / \mathrm{ml}$ TGF $\beta 1$ in the absence (DMSO vehicle) or presence of lindane for an additional 24 or $48 \mathrm{~h}$. Scrape loading-dye transfer assay using Lucifer Yellow (LY) and the relative quantitative analysis were conducted as described in the Materials and Methods. Representative photographs of 48-h treatment groups from one experiment are presented. The extent of cell coupling was determined by the number of LY positive cells (the total number of dye positive cells / the cell number on the scraped edge) and the fluorescent intensity (total fluorescent intensity / the cell number on the scraped edge). Data are expressed as the mean ( \pm s.E.) number of LY positive cells (or fluorescent intensity) relative to that of the respective control value from three independent experiments. Different lower-case letters indicate significant differences among treatment groups $(P<0 \cdot 05)$. Note that both quantitative analyses show similar results.

study (Ke et al. 2004), FSH increased the levels of StAR protein (but not P450scc enzyme) in rat granulosa cells (Figures 6 \& 7 respectively). FSH together withTGF $\beta 1$ dramatically increased the levels of both StAR protein and P450scc enzyme, while TGF $\beta 1$ alone had no effect on the levels of both proteins (Figures $6 \& 7$ respectively). Interestingly, this study demonstrates for the first time that lindane significantly reduced the FSH plus TGF $\beta 1$ -

Control

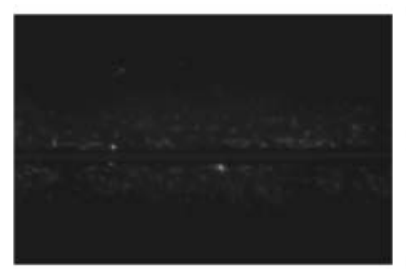

$\mathrm{FSH}+\mathrm{TGF} \beta 1$
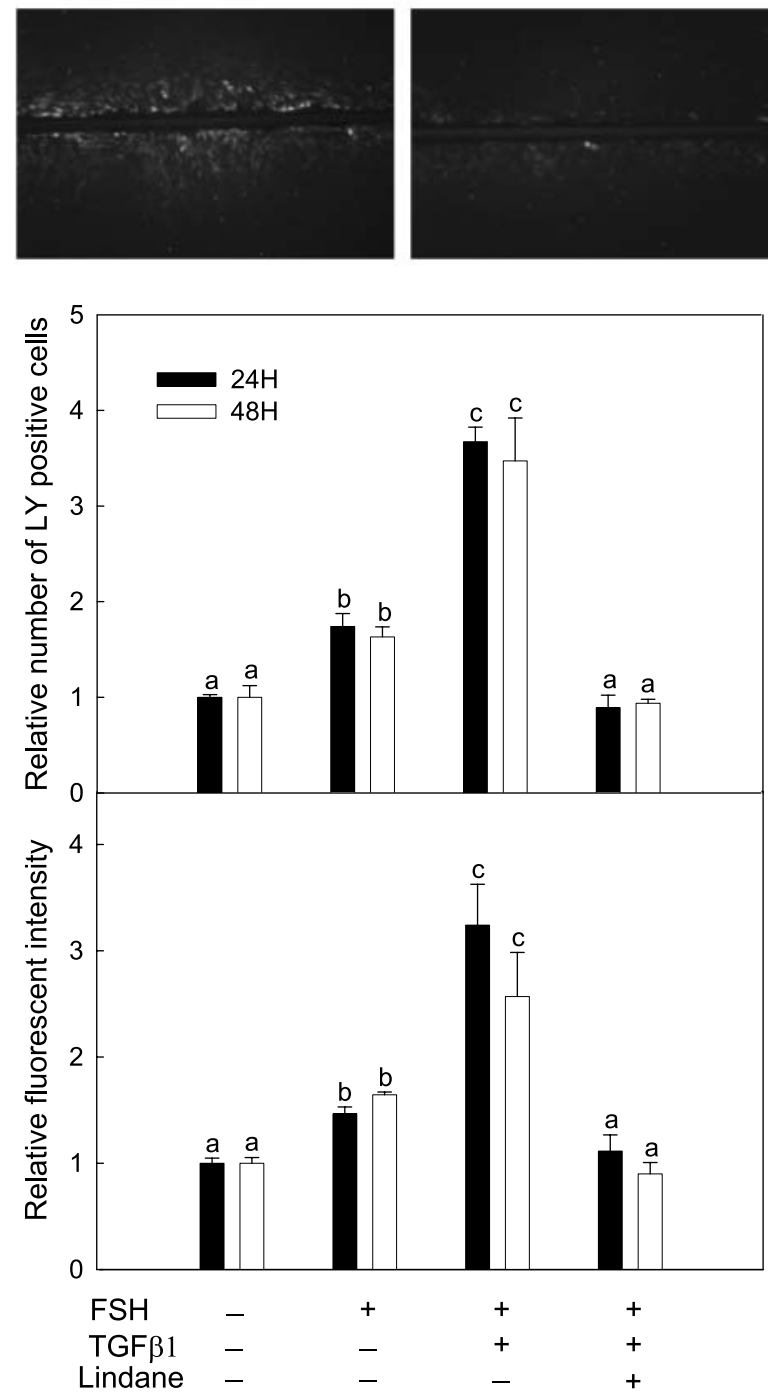


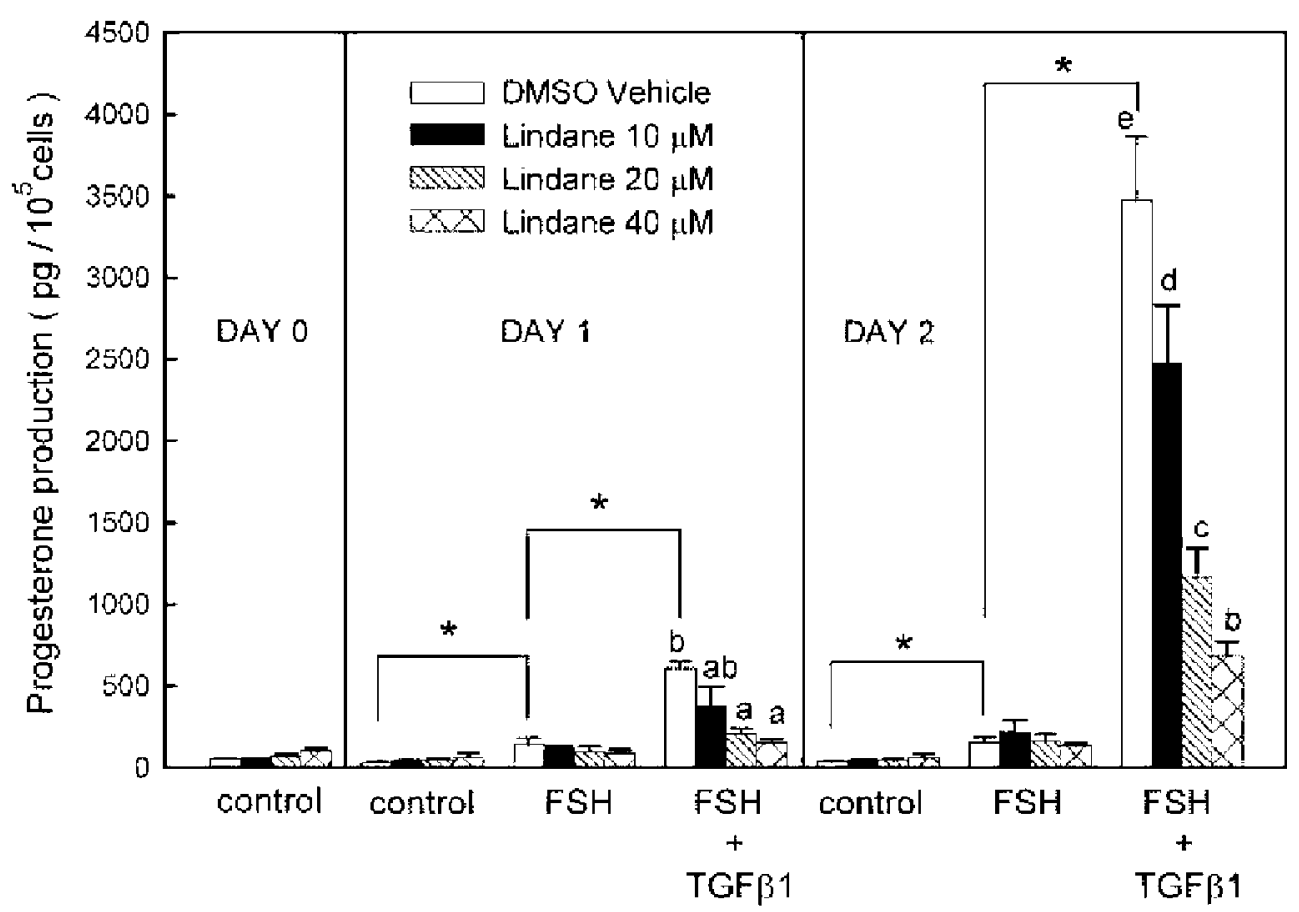

Figure 5. Dose-dependent effects of lindane (a nonselective gap junction blocker) on FSH and TGF $\beta 1$-regulated progesterone production in rat ovarian granulosa cells. Cells were plated and allowed to attach for $24 \mathrm{~h}$, pretreated with DMSO vehicle or $40 \mu \mathrm{M}$ lindane for $24 \mathrm{~h}$ (DAY 0), and then treated with vehicle, $10 \mathrm{ng} / \mathrm{ml} \mathrm{FSH}$ and/or $5 \mathrm{ng} / \mathrm{ml} \mathrm{TGF} \beta 1$ in the absence (DMSO vehicle) or presence of lindane for an additional $24 \mathrm{~h}$ (DAY 1) or $48 \mathrm{~h}$ (DAY 2). Progesterone levels in conditioned media were analyzed using enzyme immunoassay. Data are expressed as the mean ( \pm S.E.) progesterone level of triplicate samples from three independent experiments. Different lower-case letters indicate significant differences among the FSH plus TGF $\beta 1$-treated groups $(P<0 \cdot 05)$. There were no significant differences among the control or the FSH-treated groups. An asterisk indicates a significant difference between the two groups $(P<0 \cdot 05)$.

induced increases in the StAR protein and P450scc enzyme levels, in which a greater suppression was observed in the P450scc enzyme level (Figures 6 \& 7). In addition, lindane increased the basal level of StAR protein but not P450scc enzyme (Figures 6 \& 7).

To further determine the specific involvement of Cx43 gap junctions in the FSH and TGF $\beta 1$-stimulated progesterone production, a $\mathrm{Cx} 43$ peptide blocker was used. Cx43 peptide blockers have been reported to interfere with gap junction communication in airway cells and aortic smooth muscle cells (Kwak \& Jongsma 1999, Boitano \& Evans 2000). A Cx43 peptide blocker inhibited the FSH and TGF $\beta 1$-stimulated progesterone production in rat ovarian granulosa cells in a dosedependent manner, while a Cx43 control peptide had no effect (Figure 8).

\section{Discussion}

Gap junctions containing predominantly $\mathrm{Cx} 43$ are well developed in granulosa cells (Mayerhofer \& Garfield 1995, Granot \& Dekel 1997, Kidder \& Mhawi 2002), and they play critical roles in ovarian functions including folliculo- genesis and oocyte meiotic maturation (Grazul-Bilska et al. 1997, Kidder \& Mhawi 2002, Gittens et al. 2003). In the present study, we demonstrate for the first time that TGF $\beta 1$ enhanced FSH-stimulated increases in the levels of the phosphorylated forms of $\mathrm{Cx} 43$ (Cx43-P1 and $\mathrm{Cx} 43-\mathrm{P} 2)$ and gap junction communication in rat ovarian granulosa cells, and lindane (a general blocker of gap junction) suppressed such increases. This study further demonstrates that disruption of gap junctions by lindane and by a specific $\mathrm{Cx} 43$ mimetic peptide blocker suppressed FSH plus TGF $\beta 1$-stimulated progesterone production in rat ovarian granulosa cells. Interestingly, there is a clear temporal association between the $\mathrm{Cx} 43$ protein level/gap junction communication and progesterone production in ovarian granulosa cells in response to FSH, TGF $\beta 1$ and lindane. In addition, this study reveals that lindane reduced the FSH plus TGF $\beta 1$-stimulated increases in P450scc enzyme and StAR protein. Together, these results indicate that TGF $\beta 1$ enhancement of FSHfacilitated progesterone production (a granulosa cell differentiation marker) in rat ovarian granulosa cells involves the regulation of gap junction function, and that lindane may impair ovarian cell steroidogenic function. 


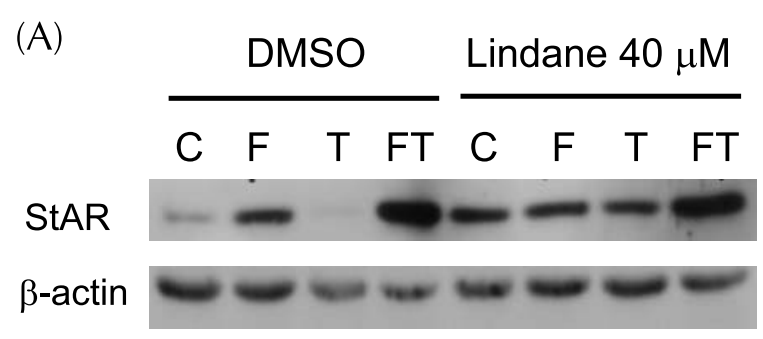

(B)

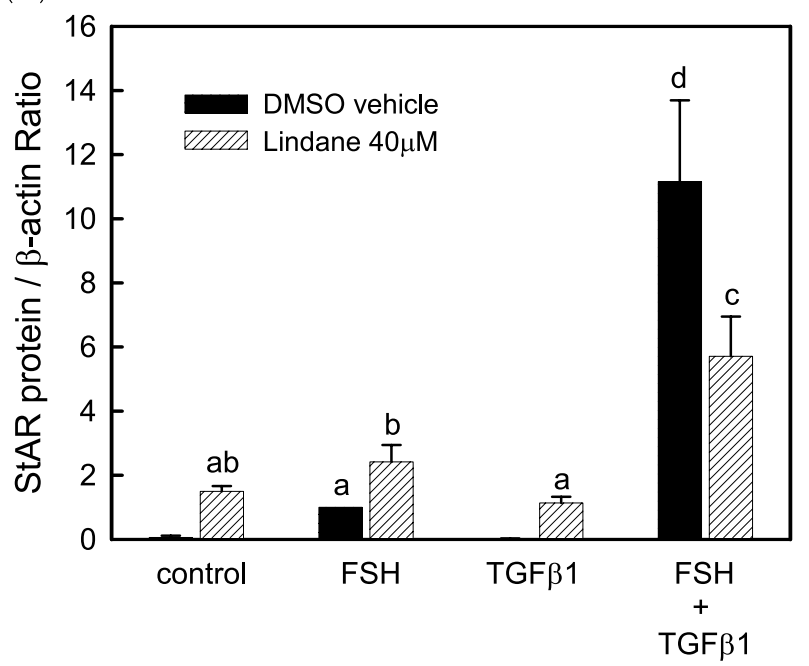

Figure 6. Effects of lindane on FSH and TGF $\beta 1$-induced StAR protein levels in rat ovarian granulosa cells. Cells were treated as described in figure 3. Cell lysates were prepared for immunoblotting analysis of StAR protein, $\beta$-actin was used as internal control and quantification was performed using scanning densitometry. Data are expressed as the mean ( \pm S.E.) density ratio of StAR: $\beta$-actin relative to that of the FSH-treated group value from four independent experiments. Different lower-case letters indicate significant differences among treatment groups $(P<0 \cdot 05)$.

At present, the understanding of the hormonal control of $\mathrm{Cx} 43$ gap junction in ovarian cells is limited. FSH may stimulate the expression of $\mathrm{Cx} 43$ as suggested by the following three lines of evidence; first, we showed that FSH moderately increased the level of phosphorylated Cx43 (Cx43-P2) in primary rat granulosa cells, while the levels of non-phosphorylated Cx43 (Cx43-NP) remained relatively low as in the control group. Secondly, a recent study reports that FSH increased the level of Cx43 mRNA in a rat ovarian granulosa cell line (Sommersberg et al. 2000). Thirdly, the expression of Cx43 was increased during gonadotropin-induced follicular growth and decreased after the ovulatory LH surge and during follicular atresia (Schreiber et al. 1993, Wiesen \& Midgley 1993, 1994, Mayerhofer \& Garfield 1995, Okuma et al. 1996, Granot \& Dekel 1997). FSH regulation of the Cx43 level or gap junction function may be mediated partly through the cAMP pathway because cAMP up-regulated the permeability of gap junctions in human granulosa cells

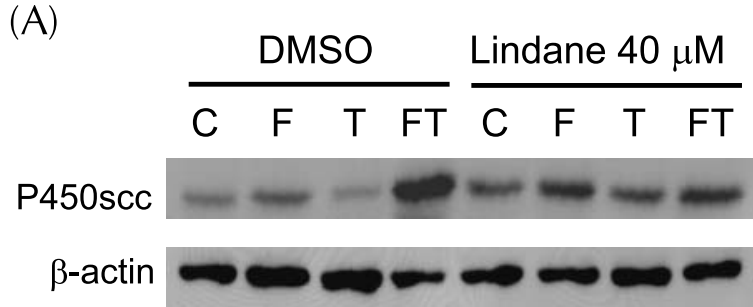

(B)

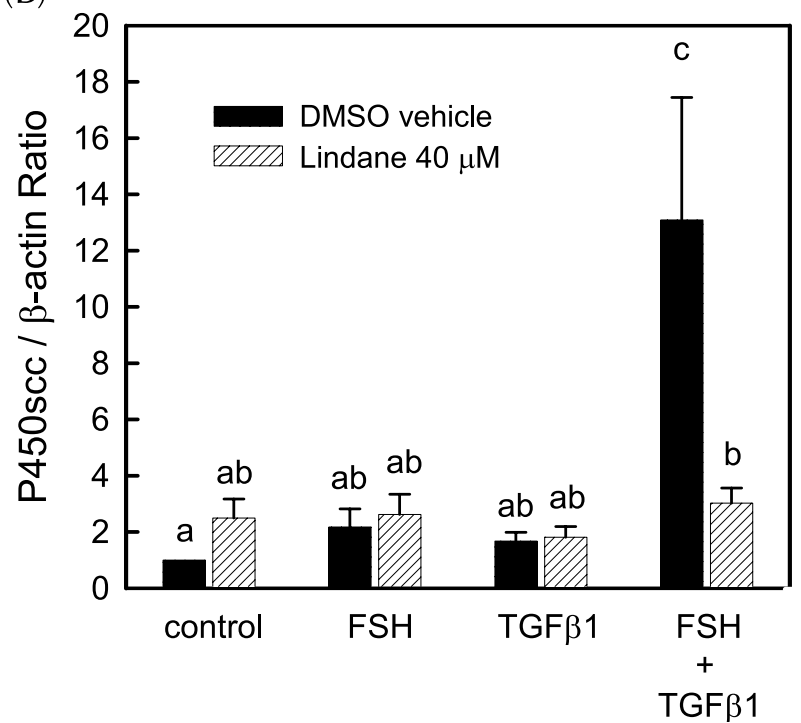

Figure 7. Effects of lindane on FSH and TGF $\beta 1$-induced P450scc enzyme levels in rat ovarian granulosa cells. Cells were treated as described in figure 3. Cell lysates were prepared for immunoblotting analysis of P450scc enzyme, $\beta$-actin was used as internal control and quantification was performed using scanning densitometry. Data are expressed as the mean $( \pm$ S.E. $)$ density ratio of P450scc: $\beta$-actin relative to that of the control group value from four independent experiments. Different lower-case letters indicate significant differences among treatment groups $(P<0 \cdot 05)$.

that also contain predominantly Cx43 (Furger et al.1996). In addition, an earlier study reported that cAMP-induced rapid increases in gap junction permeability may be partly attributed to the increase in trafficking and/or assembly of $\mathrm{Cx} 43$ in plasma membrane gap junctional plaques, a phenomenon seen in many cell types including rat granulosa cells, hepatocytes and myometrial cells (Burghardt et al. 1995). On the other hand, TGF $\beta 1$ was reported to increase Cx43 mRNA and protein levels in endothelial cells (Larson et al. 1997), and to inhibit gap junction intercellular communication and decrease the phosphorylation of Cx43 in osteoblasts (Wyatt et al. 2001) and brain cells (Robe et al. 2000). However, we did not observe any significant effect of TGF $\beta 1$ alone on the protein level of Cx43 in rat ovarian granulosa cells, yet TGF $\beta 1$ greatly augmented the FSH-stimulated increase in $\mathrm{Cx} 43$ protein level and its localization to plasma membrane plaques. We 


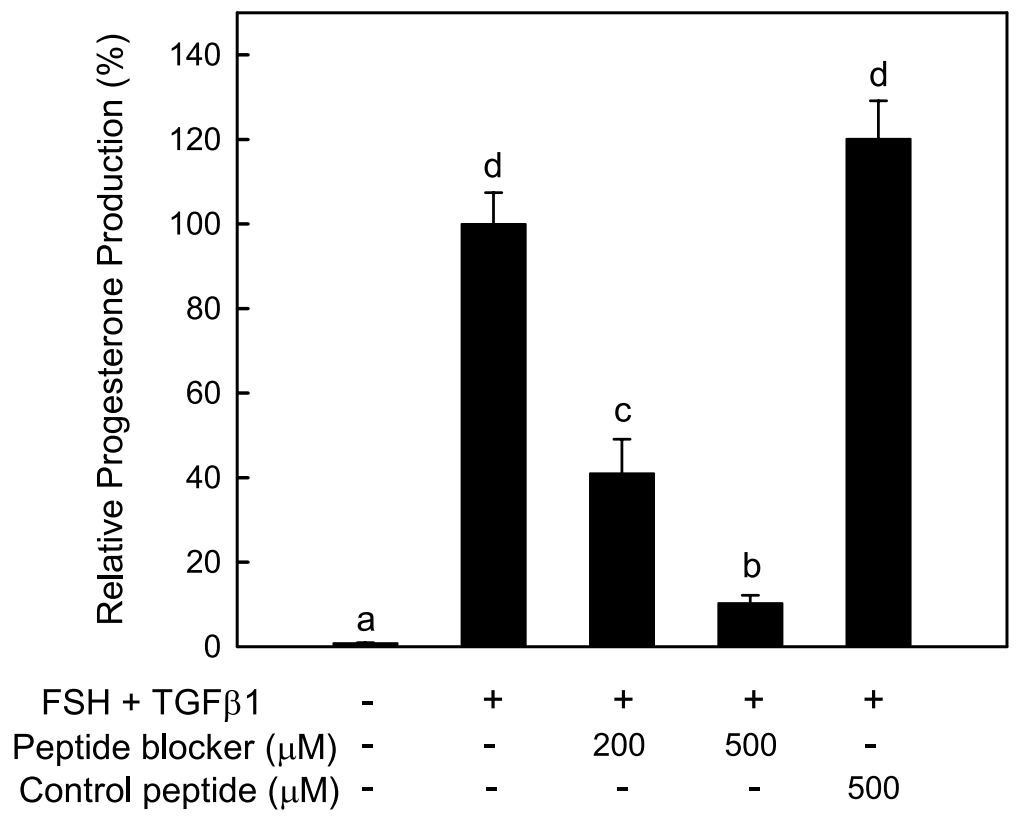

Figure 8. Effect of $\mathrm{Cx} 43$ mimetic peptide (a selective gap junction blocker) on FSH and TGF $\beta 1$-stimulated progesterone production in rat ovarian granulosa cells. Cells were given $\mathrm{Cx} 43$ peptide blocker or control peptide during plating and allowed to attach for $24 \mathrm{~h}$, pretreated with peptides for another $24 \mathrm{~h}$, and then treated with vehicle or $10 \mathrm{ng} / \mathrm{ml} \mathrm{FSH}$ plus $5 \mathrm{ng} / \mathrm{ml} \mathrm{TGF} \beta 1$ in the absence or presence of the Cx43 peptides for an additional $48 \mathrm{~h}$. Progesterone levels in conditioned media were analyzed using enzyme immunoassay. Relative progesterone production was calculated using the mean progesterone production $\left(\mathrm{pg} / 1 \times 10^{5}\right.$ cells) of FSH plus TGF $\beta 1$-treated group as $100 \%$. Data are expressed as the mean ( \pm S.E.) percentage of progesterone level of triplicate samples from three independent experiments. Different lower-case letters indicate significant differences among treatment groups $(P<0 \cdot 05)$.

cannot, at the present time, rule out the possibility that FSH and TGF $\beta 1$ may affect the turnover of $\mathrm{Cx} 43$.

The gap junction protein $\mathrm{Cx} 43$ is present in multiple phosphorylated forms in the plasma membrane of ovarian follicular cells (Godwin et al. 1993, Granot \& Dekel 1994), a finding that is also true in our present study. In vivo studies demonstrated that gonadotropin or estrogen induction of follicular growth was accompanied by an increase in the levels of Cx43 protein and mRNA with concurrent induction of the phosphorylation of $\mathrm{Cx} 43$ protein, while LH down-regulated the Cx43 gene concomitantly with its stimulation of ovulation and corpus luteum formation (Schreiber et al. 1993, Granot \& Dekel 1997). The current in vitro study also demonstrated that $\mathrm{FSH}$ increased the level of phosphorylated $\mathrm{Cx} 43$ and gap junction communication in rat ovarian granulosa cells, and that the effect of FSH was enhanced by TGF $\beta 1$. The phosphorylation of Cx43 may occur through protein kinase A (PKA)- and protein kinase C (PKC)-dependent pathways (Godwin et al. 1993, Granot \& Dekel 1994). FSH or PKA catalytic subunit could reverse the PKA inhibitor-induced reduction of cell-cell communication in primary granulosa cells (Godwin et al. 1993). In addition, cell-cell communication stopped when cells were injected with alkaline phosphatase but returned either spontaneously within $20 \mathrm{~min}$ or within 2-3 min after injection with PKA catalytic subunit or PKC (Godwin et al. 1993). Together, these studies suggest that phosphorylation of $\mathrm{Cx} 43$ in granulosa cells is essential for cell-cell communication, and that FSH may act partly through PKA in promoting the phosphorylation of $\mathrm{Cx} 43$.

The present study employed a general chemical blocker of gap junctions, lindane, to explore the potential role of gap junctions in steroidogenesis, and showed that lindane suppressed FSH plus TGF $\beta 1$-stimulated progesterone production in rat ovarian granulosa cells. It was of interest to attempt to determine the mechanism(s) whereby lindane inhibits hormone-induced steroidogenesis. Lindane has been shown to be a nonselective inhibitor of inositol metabolism as it moderately inhibits the activity of phosphatidylinositol synthase (Parries \& Hokin-Neaverson 1985). Recently, lindane was reported to impair gap junction intercellular communication by promoting the intracellular localization of $\mathrm{Cx} 43$ within the $\mathrm{Rab} 5$ positive endosomes in a Sertoli cellline (Mograbi et al. 2003). This effect of lindane requires Cx43 phosphorylation and acti- 
vation of the extracellular signal-regulated kinases (ERK) but not c-Jun N-terminal kinase and p38 mitogenactivated protein kinase (Mograbi et al. 2003). Our present study also shows that lindane reduced the levels of phosphorylated $\mathrm{Cx} 43$ and the cell surface immunostaining intensity, as well as gap junction communication in $\mathrm{FSH}$ and TGF $\beta 1$-stimulated ovarian granulosa cells. In addition, lindane was reported to inhibit gap junction communication in rat uterine myocytes through an arachidonic acid-sensitive and cAMP-independent mechanism though lindane increased the levels of intracellular cAMP (Criswell \& Loch-Caruso 1995). Also, lindane inhibited myometrial gap junctions and spontaneous oscillatory contraction by a phospholipase C-mediated pathway (Wang \& Loch-Caruso 2002). Together, these studies indicate that lindane may act through phospholipase C/inositol phosphate, ERK and arachidonic acid pathways, but not through the cAMP pathway, to inhibit gap junction communication. Whether this is true for the inhibitory effect of lindane on FSH and TGF $\beta 1$-induced increases of $\mathrm{Cx} 43$ protein level, gap junction communication and steroidogenic activity in ovarian granulosa cells awaits future study. In addition, this study demonstrates that lindane suppression of the FSH and TGF $\beta 1$-induced increases of Cx43-P2 and Cx43-P1 levels was not due to dephosphorylation since no increase in the nonphosphorylated $(\mathrm{Cx} 43-\mathrm{NP})$ form was evident. This is consistent with an earlier study in rat liver epithelial cells (Guan \& Ruch 1996). These results suggested that lindane may affect the synthesis and/or degradation of $\mathrm{Cx} 43$ but not its phosphorylation.

Consistent with our most recent study (Ke et al. 2004), this study demonstrates that FSH increased the levels of StAR protein in rat ovarian granulosa cells and TGF $\beta 1$ augmented the FSH effect. Also, FSH together with TGF $\beta 1$ increased the level of the P450scc enzyme. Interestingly, this study demonstrates for the first time that lindane exhibits differential regulation of the levels of StAR protein and $\mathrm{P} 450 \mathrm{scc}$ enzyme in rat ovarian granulosa cells. Lindane $(40 \mu \mathrm{M})$ suppressed the FSH plus TGF $\beta 1$-induced increase in the P450scc enzyme level without affecting its basal level. In addition, lindane moderately reduced the FSH plus TGF $\beta 1$-induced, but not the FSH-induced, increase in StAR protein level. Also, lindane increased the basal level of StAR protein. This indicates that lindane inhibition of FSH and TGF $\beta 1$ stimulated steroidogenesis may partly attribute to its suppression of the levels of P450scc enzyme and StAR protein. In addition, a recent report demonstrated that lindane inhibited dibutyryl cAMP-stimulated progesterone production in the mouse MA-10 Leydig tumor cell line, and in contrast to our study, lindane reduced the StAR protein level but not the P450scc enzyme level (Walsh \& Stocco 2000). At this point, we can only assume the difference may be due to the differences in the cell types utilized, as well as in the crosstalk between lindane and different stimulants (cAMP or FSH plus TGF $\beta 1$ ). Although we observed that lindane increased the basal level of StAR protein but not P450scc enzyme in rat granulosa cells, lindane had no significant effect on basal progesterone production. We further examined the specific role of $\mathrm{Cx} 43$ gap junctions in the FSH and TGF $\beta 1$-regulated steroidogenesis in rat granulosa cells by employing a specific $\mathrm{Cx} 43$ mimetic peptide blocker; the result shows that the $\mathrm{Cx} 43$ peptide blocker dosedependently reduced the FSH plus TGF $\beta 1$-stimulated progesterone production.

Overall, the present study suggests that Cx43 gap junction formation may play a critical role in FSH plus TGF $\beta 1$-promoted steroidogenesis in rat ovarian granulosa cells. Lindane may repress female reproductive function partly through negative regulation of ovarian steroidogenic activity.

\section{Acknowledgements}

We appreciate the generous gift of P450scc enzyme antisera by Dr Bon-Chu Chung (Academia Sinica, Taipei, Taiwan). We also thank Mr Yi-Jen Hsueh for his technical assistance in the preparation of graphic information. This study was supported by grants from the National Science Council of Taiwan NSC90-2320-B-010-070 and NSC91-2320-B-010-059 (to J-J H), the Council of Agriculture of Taiwan 90-1·4·5-F1 (to F-C K), NSC912320-B-001-054 (to M-T L), and by grant HD17481 from the National Institutes of Health and funds from the Robert A Welch Foundation (to D M S). The authors declare that there is no conflict of interest that would prejudice the impartiality of this scientific work.

\section{References}

Ackert CL, Gittens JEI, O’Brien MJ, Eppig JJ \& Kidder GM 2001 Intercellular communication via connexin 43 gap junctions is required for ovarian folliculogenesis in the mouse. Developmental Biology 233 258-270.

Benahmed M, Morera AM, Ghiglieri C, Tabone E, Menezo Y, Hendrick JC \& Franchimont P 1993 Transforming growth factor- $\beta$ s in the ovary. Annals of the New York Academy of Sciences 687 13-19.

Boitano S \& Evans WH 2000 Connexin mimetic peptides reversibly inhibit $\mathrm{Ca} 2+$ signaling through gap junctions in airway cells. American Journal of Physiology - Lung, Cellular and Molecular Physiology 279 L623-L630.

Burghardt RC \& Matheson RL 1982 Gap junction amplification in rat ovarian granulosa cells. I. A direct response to follicle-stimulating hormone. Developmental Biology 94 206-215.

Burghardt RC, Barhoumi R, Sewall TC \& Bowen JA 1995 Cyclic AMP induces rapid increases in gap junction permeability and changes in the cellular distribution of connexin43. Journal of Membrane Biology 148 243-253.

Christenson LK \& Strauss JF Jr 2001 Steroidogenic acute regulatory protein: an update on its regulation and mechanism of action. Archives of Medical Research 32 576-586. 
Clark BJ, Wells J, King SR \& Stocco DM 1994 The purification, cloning, and expression of a novel luteinizing hormone-induced mitochondrial protein in MA-10 mouse Leydig tumor cells. Characterization of the steroidogenic acute regulatory protein (StAR). Journal of Biological Chemistry 269 28314-28322.

Criswell KA \& Loch-Caruso R 1995 Lindane-induced elimination of gap junctional communication in rat uterine myocytes is mediated by an arachidonic acid-sensitive cAMP-independent mechanism. Toxicology and Applied Pharmacology 135 127-138.

Dalsenter PR, Faqi AS, Webb J, Merker HJ \& Chahoud I 1996 Reproductive toxicity and tissue concentrations of lindane in adult male rats. Human and Experimental Toxicology 15 406-410.

Defamine N, Mograbi B, Roger C, Cronier L, Malassine A, Brucker-Davis F, Fenichel P, Segretain D \& Pointis G 2001 Disruption of gap junction intercellular communication by lindane is associated with aberrant localization of connexin 43 and zonula occludens-1 in 42 GPA9 Sertoli cells. Carcinogenesis 22 1537-1542.

Dorrington JH, Bendell JJ \& Khan SA 1993 Interactions between FSH, estradiol- $17 \beta$ and transforming growth factor- $\beta$ regulate growth and differentiation in the rat gonad. Journal of Steroid Biochemistry and Molecular Biology 44 441-447.

El-Fouly MH, Trosko JE \& Chang CC 1987 Scrape-loading and dye transfer: a rapid and simple technique to study gap junctional intercellular communication. Experimental Cell Research 168 422-430.

El-Sabban ME, Sfeir AJ, Daher MH, Kalaany NY, Bassam RA \& Talhouk RS 2003 ECM-induced gap junctional communication enhances mammary epithelial cell differentiation. Journal of Cell Science 116 3531-3541.

Furger C, Cronier L, Poirot C \& Pouchelet M 1996 Human granulosa cells in culture exhibit functional cyclic AMP-regulated gap junctions. Molecular Human Reproduction 2 541-548.

Gillies RJ, Didier N \& Denton M 1986 Determination of cell number in monolayer cultures. Analytical Biochemistry 159 106-113.

Gittens JEI, Mhawi AA, Lidington D, Ouellette Y \& Kidder GM 2003 Functional analysis of gap junctions in ovarian granulosa cells: distinct role for connexin 43 in early stages of folliculogenesis. American Journal of Physiology - Cell Physiology 284 C880-C887.

Godwin AJ, Green LM, Walsh MP, McDonald JR, Walsh DA \& Fletcher WH 1993 In situ regulation of cell-cell communication by the cAMP-dependent protein kinase and protein kinase C. Molecular and Cellular Biochemistry 127-128 293-307.

Granot I \& Dekel N 1994 Phosphorylation and expression of connexin-43 ovarian gap junction protein are regulated by luteinizing hormone. Journal of Biological Chemistry 269 30502-30509.

Granot I \& Dekel N 1997 Developmental expression and regulation of the gap junction protein and transcript in rat ovaries. Molecular Reproduction and Development 47 231-239.

Grazul-Bilska AT, Reynolds LP \& Redmer DA 1997 Gap junctions in the ovaries. Biology of Reproduction 57 947-957.

Guan X \& Ruch RJ 1996 Gap junction endocytosis and lysosomal degradation of connexin43-P2 in WB-F344 rat liver epithelial cells treated with DDT and lindane. Carcinogenesis 17 1791-1798.

Guan X, Bonney WJ \& Ruch RJ 1995 Changes in gap junction permeability, gap junction number, and connexin 43 expression in lindane-treated rat liver epithelial cells. Toxicology and Applied Pharmacology 130 79-86.

Hirshfield AN 1991 Development of follicles in the mammary ovary. International Review of Cytology 124 43-101.

Hu M-C, Guo I-C, Lin J-H \& Chung B-C 1991 Regulated expression of cytochrome P-450 SCC (cholesterol-side-chain cleavage enzyme) in cultured cell lines detected by antibody against bacterially expressed human protein. Biochemical Journal $\mathbf{2 7 4}$ 813-817.

Hwang J-J, Lin S-W, Teng C-H, Ke F-C \& Lee M-T 1996 Relaxin modulates the ovulatory process and increases secretion of different gelatinases from granulose and theca-interstitial cells in rats. Biology of Reproduction $\mathbf{5 5}$ 1276-1283.
Inoue K, Nakamura K, Abe K, Hirakawa T, Tsuchiya M, Matsuda H, Miyamoto K \& Minegishi T 2002 Effect of transforming growth factor $\beta$ on the expression of luteinizing hormone receptor in cultured rat granulosa cells. Biology of Reproduction $\mathbf{6 7}$ 610-615

Juneja SC, Barr KJ, Enders GC \& Kidder GM 1999 Defects in the germ line and gonads of mice lacking connexin43. Biology of Reproduction $601263-1270$.

Ke F-C, Chuang L-C, Lee M-T, Lin S-W, Wang PS, Stocco DM \& Hwang J-J 2004 The modulatory role of TGF $\beta 1$ and androstenedione on FSH-induced gelatinase secretion and steroidogenesis in rat granulosa cells. Biology of Reproduction $\mathbf{7 0}$ 1292-1298.

Kidder GM \& Mhawi AA 2002 Gap junctions and ovarian folliculogenesis. Reproduction 123 613-620.

Kumar NM \& Gilula NB 1996 The gap junction communication channel. Cell 84 381-388.

Kwak BR \& Jongsma HJ 1999 Selective inhibition of gap junction channel activity by synthetic peptides. Journal of Physiology (London) 516 679-685.

Larson DM, Wrobleski MJ, Sagar GD, Westphale EM \& Beyer EC 1997 Differential TGF-beta1. American Journal of Physiology - Cell Physiology 272 C405-C415.

Larson DM, Christensen TG, Sagar GD \& Beyer EC 2001 TGF-beta1 induces an accumulation of connexin 43 in a lysosomal compartment in endothelial cells. Endothelium 8 255-260.

Lindenau A, Fischer B, Seiler P \& Beier HM 1994 Effects of persistent chlorinated hydrocarbons on reproductive tissues in female rabbits. Human Reproduction 9 772-780.

Lu SS, Lau CP, Tung YF, Huang SW, Chen YH, Shih HC, Tsai SC, Lu CC, Wang SW, Chen JJ, Chien EJ, Chien CH \& Wang PS 1996 Lactate stimulates progesterone secretion via an increase in cAMP production in exercised female rats. American Journal of Physiology - Endocrinology and Metabolism 271 E910-E915.

Mayerhofer A \& Garfield RE 1995 Immunocytochemical analysis of the expression of gap junction protein connexin 43 in the rat ovary. Molecular Reproduction and Development 41 331-338.

Mograbi B, Corcelle E, Defamie N, Samson M, Nebout M, Segretain D, Fenichel P \& Pointis G 2003 Aberrent connexin 43 endocytosis by the carcinogen lindane involves activation of the ERK/mitogen-activated protein kinase pathway. Carcinogenesis 24 $1415-1423$.

Okuma A, Kuraoka A, Iida H, Inai T, Wasano K \& Shibata Y 1996 Colocalization of connexin 43 and connexin 45 but absence of connexin 40 in granulosa cell gap junctions of rat ovary. Journal of Reproduction and Fertility 107 255-264.

Parries GS \& Hokin-Neaverson M 1985 Inhibition of phosphatidylinositol synthase and other membrane-associated enzymes by stereoisomers of hexachlorocyclohexane. Journal of Biological Chemistry 260 2687-2693.

Pluciennik F, Joffre M \& Deleze J 1994 Follicle-stimulating hormone increases gap junction communication in Sertoli cells from immature rat testis in primary culture. Journal of Membrane Biology 139 81-96.

Richards JS 2001 Perspective: the ovarian follicle - a perspective in 2001. Endocrinology 142 2184-2193.

Robe PA, Rogister B, Merville MP \& Bours V 2000 Growth regulation of astrocytes and C6 cells by TGFbeta1: correlation with gap junctions. Neuroreport 11 2837-2841.

SAS 1999 SAS/STAT User's Guide, version 8. Cary, NC: SAS Institute Inc.

Schreiber JR, Beckmann MW, Polacek D \& Davies PF 1993 Changes in gap junction connexin-43 messenger ribonucleic acid levels associated with rat ovarian follicular development as demonstrated by in situ hybridization. American Journal of Obstetrics and Gynecology 168 1094-1104. 
Sommersberg B, Bulling A, Salzer U, Frohlich U, Garfield RE, Amsterdam A \& Meyerhofer A 2000 Gap junction communication and connexin 43 gene expression in a rat granulosa cells line: regulation by follicle-stimulating hormone. Biology of Reproduction $\mathbf{6 3}$ 1661-1668.

Stocco DM 2001 Tracking the role of a star in the sky of the new millennium. Molecular Endocrinology 15 1245-1254.

Szymczynski GA \& Waliszewski SM 1983 Chlorinated pesticide residues in testicular tissue samples. Pesticides in human testicles. Andorlogia 15 696-698.

Walsh LP \& Stocco DM 2000 Effect of lindane on steroidogenesis and steroidogenic acute regulatory protein expression. Biology of Reproduction 63 1024-1033.

Wang CT \& Loch-Caruso R 2002 Phospholipase-mediated inhibition of spontaneous oscillatory uterine contraction sby lindane in vitro. Toxicology and Applied Pharmacology 182 136-147.

Wiesen JF \& Midgley AR Jr 1993 Changes in expression of connexin 43 gap junction messenger ribonucleic acid and protein during ovarian follicular growth. Endocrinology 133 741-746.
Wiesen JF \& Midgley AR Jr 1994 Expression of connexin 43 gap junction messenger ribonucleic acid and protein during follicular atresia. Biology of Reproduction 50 336-348.

Wyatt LE, Chung CY, Carlsen B, Iida-Klein A, Rudkin GH, Ishida K, Yamaguchi DT \& Miller TA 2001 Bone morphogenetic protein-2 (BMP-2) and transforming growth factor-beta1 (TGF-beta1) alter connexin43 phosphorylation in MC3T3-E1 cells. BMC Cell Biology 214.

Yamasaki H \& Naus CCG 1996 Role of connexin genes in growth control. Carcinogenesis 17 1199-1213.

Yeh S-L \& Hu M-L 2003 Oxidized $\beta$-carotene inhibits gap junction intercellular communication in the human lung adenocarcinoma cell line A549. Food and Chemical Toxicology 41 1677-1684.

Received 18 December 2004

Accepted 23 December 2004

Made available online as an

Accepted Preprint 7 January 2005 